\title{
Strategy for Improving the Quality of Teaching Islamic Religious Education Program in Kopertais Region 1 Jakarta Interpretive Structural Model (ISM) Approach
}

\author{
Milana Abdillah Subarkah ${ }^{1 *}$, Suhendar Sulaeman ${ }^{2}$, Oneng N Bariyah ${ }^{3}$ \\ ${ }^{1}$ Muhammadiyah of University Tangerang \\ ${ }^{2,3}$ Muhammadiyah of University Jakarta
}

DOI: $10.36348 /$ sjhss.2020.v05i04.007

| Received: 04.04.2020 | Accepted: 19.04.2020 | Published: 30.04 .2020

*Corresponding author: Milana Abdillah Subarkah

\section{Abstract}

This research is a qualitative research with the aim of analyzing the strategy of improving the quality of lecturers of Islamic Religious Education study programs in Kopertais Region 1 DKI Jakarta with the Interpretive Structural Model (ISM) approach. Some of the elements that are the focus of this study include the main obstacles, program objectives, and related institutions. And the results of the study show: First, the main obstacle element. The thing that needs to be prioritized to be improved is the promotion of the functional description of the academic lecturers of Islamic Religious Education and research and community service activities. Second, the element of program objectives. Namely formulating a program of achievement for Islamic Religious Education lecturers who are professional, accomplished and certified. Third, the related institutional elements. From each institution which has authority to improve the quality of lecturers of Islamic Religious Education, they can work together.

Keywords: Strategy, Quality, Lecturer, ISM.

Copyright @ 2020: This is an open-access article distributed under the terms of the Creative Commons Attribution license which permits unrestricted use, distribution, and reproduction in any medium for non-commercial use (NonCommercial, or CC-BY-NC) provided the original author and source are credited.

\section{INTRODUCTION}

The development of the science and technology so quickly and rapidly in many parts of the world, resulting in globalization. It is characterized by the spread of information and communication relations between nations and countries. Of global progress quickly and rapidly certainly have positive and negative impacts in society. The negative impact of the globalization development spawned a wide range of global issues. Global problem, especially in the aspect of education experienced by some nations in the world such as the declining quality of students' problems, increasing social inequality, erosion of local culture and other educational problems [1].

In addition to the negative impact of globalization also have a positive impact on the development of the times, especially in the field of global education such as ease of access to education, teaching and learning educational systems do not always face to face (e-learning), increasing the quality of education, and so on.
Education is an investment in human resources will never lose and also have added value to the life of the nation. Especially in the midst of many people in Indonesia are increasingly aware of the investment in education in order to face globalization and competition [2].

As the great expectations of society on the role of religious Islamic College, then now is the public demands of the quality of Islamic education became stronger when there is a change in society wider viewpoint of the effects of globalization with the pattern of economic thought more transparent.

Then, in an effort to create a quality education that is charged to the organizers of universities, both public universities and private universities, has become a necessity of the organizers to continue to innovate in order to confront a wide range of issues, threats, and challenges faced. So also in this aspect of the study program specialization in quantity the number of students is still a determinant in the activities of the college first private college to get the maximum number of students in the midst of a very tight competition between universities. As expressed by the former 
Minister of Research Technology and Higher Education in 2019 M. Nasir targeting Indonesian universities should be in the top three in ASEAN (Southeast Asia).

Competition locally, nationally, and even internationally became no less fierce in competition to win the new students, existing in urban areas and with the intention of doing further studies at public and private universities. Within the individual universities are competing to provide the best education for its students [3].

In this regard, as of 2018 data in Kopertais Region 1 DKI Jakarta, there are 64 PTKIS that have been fostered, but there are still a number of universities that have received $\mathrm{C}$ accreditation, and some even have expired accreditation status. Meanwhile, the number of Islamic religious education study programs in Kopertais Region 1 DKI Jakarta is 36 PTKIS. Each accreditation from Islamic religious education study program in Kopertais Region 1 DKI Jakarta is as follows:

Table-1: Accreditation of Islamic Religious Education Study Programs

\begin{tabular}{|c|c|c|}
\hline NO & ACCREDITATION & AMOUNT \\
\hline 1 & A & 7 \\
\hline 2 & B & 20 \\
\hline 3 & C & 9 \\
\hline \multicolumn{2}{|c|}{ AMOUNT } & 36 \\
\hline
\end{tabular}

Sources: Kopertais Wilayah 1 DKI Jakarta

From these data shows that the Islamic religious education study program, has not met the desired expectations as stated by the Ministry of Research, Technology and Higher Education. Of course this has become a separate challenge for DKI Jakarta Kopertais Region 1 to increase the accreditation of Islamic religious education study programs as a target.

Accreditation of educational institutions is largely determined by its human resources (Islamic religious education lecturers). Which directly plays a role in determining the quality of education, the human resources of the Islamic Religious Higher Education Institution besides aiming to improve and develop the quality of education, also become one of the key factors in increasing competitive advantage or competitiveness among educational institutions[4], The low activity of research and community service which is the main trigger, and in terms of functional positions lecturers of Islamic religious education study programs.

Improving the quality of Islamic higher education in the midst of its development is needed. Maintained competitive Taking prospective students is a special attraction to do. Therefore, in order to achieve the desired award from higher education institutions in the hope of improving the quality of special education Islamic Religious Education study programs in Kopertais Region 1 DKI Jakarta. So it takes a variety of strategies needed to provide support for human resources teaching religious education to improve quality and competence.

Mesra. B in Farchan proposed strategy is a process of evaluating the strengths and weaknesses of the company / organization compared to the opportunities and threats that exist in the environment at hand and decide on a strategy that adapts to market products the ability of companies / organizations with environmental opportunities. Strategy is the target pattern, intent or purpose and policy, and plans necessary to achieve that objective, expressed as a business establishes adopted by a company / organization, and the type or about to become what the company / organization is [5].

Strategy is also a plan that has a broad and integrated scale in order to achieve the mission and goals of the organization by creating competitive advantage to overcome environmental changes that occur in the future. Human resource management strategy is a must for companies/organizations to implement in balancing technical human resource management so that the human resources of the company/organization are difficult to be imitated by the challenges that occur.

Human resource management is a discussion that occupies a strategic position in the organizational system, including Islamic religious higher education institutions, therefore it must be continuously studied and found at the bottom of how the management model of management of human resource management [5]. As Samsul Hadi said in Fauzi, that improving the quality of education is essentially in the management of human resources. The same thing was stated by Winoto in his research on the management of human resources in Islamic Education institutions which became quite serious study material, this is due to the existence of human resources which could significantly influence the culture of performance and improvement of the quality of Islamic education [5].

In terms of its objectives, human resource management is an effort to increase the contribution of individuals contained in the organization through several ways that can be accounted for ethically, strategically, and socially [6]. Effective human resource management requires leaders of Islamic education institutions to formulate the best way of employing their staff to achieve the goals of the institution he leads. Efficient use of the potential of staff involves understanding individual needs so that staff abilities can be explored and utilized to the full and sustainable.

The duties and responsibilities of lecturers have been explained in Law No. 14 of 2005, there were three main tasks of lecturers, namely tasks in the fields of education, research, and community service 
(tridharma). Of the three fields, it is inseparable from the position attached to the lecturer, namely as a professional educator and scientist in accordance with his discipline or expertise. From some of the lecturers' task fields in detail can be explained as follows[7].

First, the task of lecturers in the field of education. In this field it is the implementation of education and learning, guidance and training of students 'skills in teaching by the lecturer, while the student relations and lecturers' duties in the implementation of education include:

a. Carry out teaching assignments using planning materials, attend on schedule, prepare for lectures, provide learning contracts, and assess objectively.

b. Recognizing students are individuals who must be respected and have rights that must be protected.

c. Give a good example to students in terms of intellectuality, academics, personal integrity, and professional ethics.

d. It is not justified if the lecturer uses his influence to convey lecture problems / material outside the competence of his profession.

Furthermore, in relation to the development of the lecturer profession, lecturers' duties may include the following:

a. Follow the development and progress of science by observing each Ministry of Research, Technology and Higher Education, attending seminars, workshops, discussions and the like.

b. Get involved in curriculum development, committee, and other scientific activities.

c. Caring for the good image of the academic and professional professors by providing guidance and motivation to new lecturers in order to become qualified lecturers, as well as providing recommendations objectively in the process of lecturer academic functional promotion.

Second, the task of carrying out research activities. Research activities according to the Decree of the Minister of National Education No.36 / D / O / 2001 on technical guidelines for the implementation of credit score assessments for academic functional lecturers include making scientific work, both thoughts and research in the form of monographs, making scientific articles published in journals, make reference books, research seminars, design, adapt, edit scientific works and patented technology works, and make monumental works of art that are displayed. This research activity received a great attention for the government through higher education policy makers in the Republic of Indonesia by providing financial assistance from published research programs. These grants and awards can include individual research, collective competitive research, and so on.

Third, the task of carrying out community service. Community activities are activities that connect the results of research and mastery of scientific disciplines in the field of education with improving the quality of education and research development, on the other hand as a support for development in various layers of society. Community service activities according to the Joint Minister of Education and Culture Decree and the Head of the BKN Year 1999 include: occupying leadership positions in government institutions that must be released from their organic positions, conducting education and research results that benefit the community, providing information to the community, providing community services, and activities others support the general tasks of government and development.

Meanwhile, Zainuddin in Piscayanti [8], said that one of the lecturers' professionalism is to obtain educator certificates as explained in the law, that lecturer certification is a process of giving educator certificates to lecturers. Lecturer certification aims to (1) assess the professionalism of lecturers in order to determine the eligibility of lecturers in carrying out their duties, (2) protect the lecturers profession as teaching and teaching staff in universities, (3) improve the quality of the process and educational outcomes, (4) accelerate in order to realize the aims of national education, and (5) giving lecturers awareness of the obligation to uphold academic integrity and ethics especially the prohibition in plagiarism. Another goal of the lecturer certification program is to provide welfare in the form of additional income outside the incentives / allowances and teaching fees. So for every lecturer the opportunity to get a lecturer certification allowance.

Professionalism is not only seen from the ability of lecturers to develop and provide learning to students, but also must be seen in terms of income so that the government must provide appropriate and feasible income. This aims to increase the needs of educators financially as referred to as the certification allowance for lecturers who have received an educator certificate. Of course, with the existence of the lecturer certification program to be a step or government policy to provide motivation / encouragement to lecturers to be enthusiastic in carrying out their duties and performance [9].

Basyar said that the quality of lecturers was seen as a process that was arranged to increase the output produced, therefore, it could be said that the final quality was a product [2]. Quality is a set of characteristics that are typical of goods or services that must be in accordance with the wishes of the user, in the context of education that is producing a quality educational service must be clarified in advance what and what the quality desired by the user.

So, in an effort to improve the quality of Islamic religious education study programs. Lecturers as educators have a major contribution in improving the 
accreditation and quality of study programs in DKI Jakarta Kopertais Region 1. Therefore, the competence of Islamic religious education lecturers is a resource of knowledge, skills and behaviors that must be possessed, mastered, and internalized by Islamic religious lecturers in carrying out their professional duties as contained in Unidang No. 14 of 2005 concerning Lecturers [10]. Kunandar in Syahrizal expressed the same thing that the quality of Islamic religious education lecturers was interpreted as a resource assignment capabilities that must exist within educators in order to be able to realize performance proportionally and optimally. All of these resources are not only limited to mastery and ownership but are also able to be realized by Islamic religious education lecturers in improving the quality of their study programs and institutions. Then qualified Islamic religious education lecturers are lecturers who have and realize their abilities in an integrated manner namely cognitive, psychomotor, and affective abilities in carrying out their obligations in the process of higher education tridharma activities.

Thus, as described above the urgency of improving the quality of Islamic religious education lecturers in order to achieve the quality of study programs and institutions of Islamic Religious Higher Education in particular and education in general. The subject matter will mainly be based on a case that occurred at a lecturer in Islamic religious education within the DKI Jakarta Kopertais Region 1 Private Islamic College. With this discussion, it is expected to contribute and as a material for further discussion in order to improve the quality of lecturers of Islamic religious education in particular.

\section{PURPOSE OF STUDY}

This study aims to answer, find out, and analyze strategies to improve the quality of Islamic religious education lecturers in Kopertais region 1 DKI Jakarta with the Interpretive Structural Model (ISM) approach.

\section{RESEARCH METHODOLOGY}

In the study the authors use qualitative methods, the analysis technique Interpretive Structural Model
(ISM). ISM is a descriptive modeling techniques and structuring tool for a direct connection. Basis for a decision in the ISM is a group technique. The resulting structural model is to analyze the complex problems of a system, through a carefully designed pattern by using graphics and sentences. Through this ISM technique, models are not clear transformed system model will be clear or visible (visible) [10],

On the part of the First Instance ISM technique is the preparation of the hierarchy. Determining the level of hierarchy can be through the five criteria are: (1) the strength of the binder (bond strength) within or between groups / levels, (2) the relative frequency of oksilasi; the lower level more quickly shaken than the next higher level, (3) the context; a higher level of operating at a slower period in the broader space, (4) the coverage; tingggi level includes the level below, and (5) a functional relationship; have a higher level variables that affect the variable slow rapidly in the lower level.

Then, the second part of the technical analysis of the ISM is to divide some of the substance being analyzed into sub-sub-elements and elements in depth until deemed adequate. The preparation of this subelement by using input from a related group. Then determine the contextual relationship between the subelements, expressed in terms of sub-ordinate towards the pairwise comparisons. Based on consideration of the contextual relationship, compiled Structural Self Interaction Matrix (SSIM), then made the table Reachability Matrix (RM) and the calculation according to Rule Transivity to make corrections to the SSIM to obtain a closed matrix. RM has met transity rule then processed to make a selection of levels (level partition). The result can be described in schematic form each element according to levels of vertical and horizontal. Based RM, sub-elements in one element can be arranged according to the Driver Power Dependence (DP-P) into four classifications or sectors namely the Independent IV (dependence), sector linkage III, sector autonomuos I and sectors autonomuos II as shown in the Figure below this [11].

\begin{tabular}{|c|c|c|}
\hline \multirow{3}{*}{ 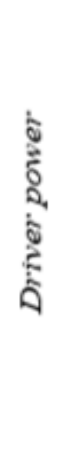 } & $\begin{array}{l}\text { IV. Independent: } \\
\text { Strong Driver weak } \\
\text { Dependent variabels }\end{array}$ & $\begin{array}{l}\text { III. Linkage: } \\
\text { Strong driver - strongly } \\
\text { Dependent variabels }\end{array}$ \\
\hline & $\begin{array}{ll}\text { I. Autonomous } \\
\text { Weak Driver - weak } \\
\text { Dependent variabels }\end{array}$ & $\begin{array}{l}\text { II. Autonomous } \\
\text { Weak Driver - strongly } \\
\text { Dependent variabels }\end{array}$ \\
\hline & & Dependence \\
\hline
\end{tabular}

Fig-1: Matrix Driver Power - Dependence

Sources: (Sianipar, 2012) 
As in the identification of issues, strategies, and things that become part of improving the quality of lecturers PAI in Kopertais Region 1 Jakarta, which then built a model framework ISM for some desired objectives, among others: (1) the main obstacle, (2) objectives of the program, and (3) the institution concerned. The stages of the research framework strategy for improving the quality of lecturers PAI in Kopertais Region 1 Jakarta, as presented in Figure 2.

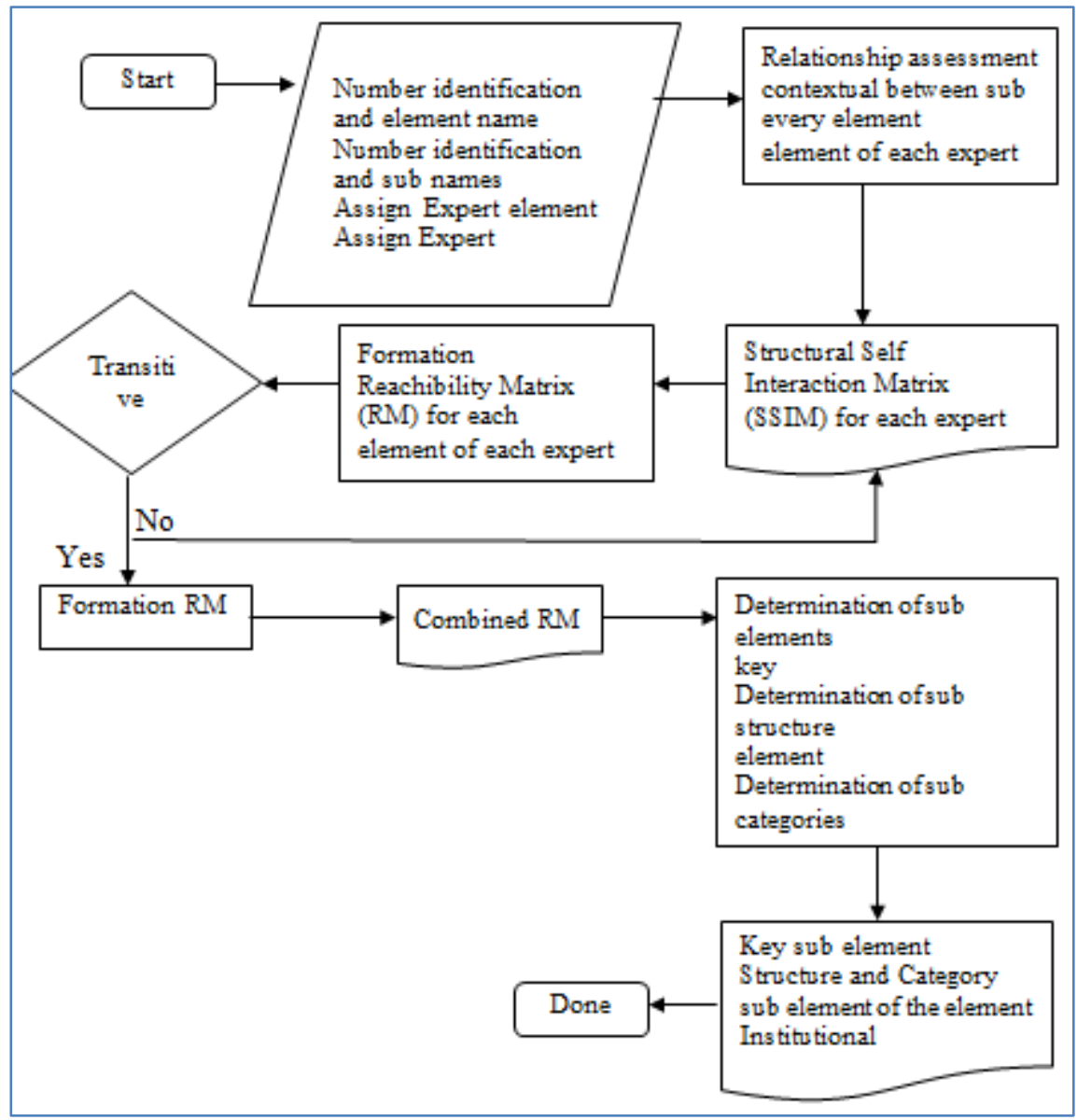

Fig-2: Stages and research framework Sources: (Sianipar, 2012)

With the improvement of the quality of lecturers PAI to build contextual ties between variables in the model, the ISM method using expert opinion with VAXO framework. Relation to this study, a group of expert groups involved in drafting a model consisting of academics, practitioners of Islamic Religious Private Universities (PTKIS) in Region 1 Jakarta Kopertais [12].

In building a model, the authors decided to use the traditional methods that are commonly used by brainstorming as in-depth interviews with experts, who in turn receives input and revise the model regularly. Some of the literature and discussion related to improving the quality of lecturers PAI also discussed with experts to validate and refine the model.

To analyze the relationship between variables or an enabler of improved quality of PAI lecturers each key constraints, program objectives, and institutions have to define how the effect of one variable to another variable: whether the influence, influenced, influences each other, or do not affect each other. Based on these data, contextual relationships between variables were constructed [13].

The panelists / experts were then asked and asked for their statements in the questionnaire format to compare statements in columns with rows for each question box by selecting values between $\mathrm{V}, \mathrm{A}, \mathrm{X}$, or $\mathrm{O}$ to represent their perceptions of the relationship between these variables [13].

\section{RESULTS OF THE RESEACH Elements Main Obstacle}

Seen in the table below, there are five variables related to the main obstacle aspects in improving the quality of lecturers in Kopertais Region 1 Jakarta Islamic religious education arranged in row and column format. Variables in rows and columns are represented in each letter I and J. Thus, each pair of variables is observed separately after lattice formation, which is 
obtained in the above process. Four keywords are used to represent the direction of the relationship between a set of variables (I and $\mathrm{J}$ ), where:

a. $\mathrm{V}$ indicates that variable I influences variable $\mathrm{J}$;

b. A indicates that the variable affects the $\mathrm{JJ}$ variable;

c. $\mathrm{X}$ indicates that the first variable influences the variable $\mathbf{J} \mathbf{J}$ and vice versa the variable influences variable $\mathrm{I}$, or in another sense there is an interaction between variables I and $\mathrm{J}$;

d. $O$ indicates that the variables $I$ and $J$ are not interconnected. The relationships between variables in the model are represented by a matrix called the structural self-interaction matrix (SSIM), with the values for each pair of variables being agreed upon among experts.

The relationships between variables in the model are represented by a matrix called the structural selfinteraction matrix (SSIM), with the values for each pair of variables being agreed upon among experts.

Table-2: Interaction Matrix Self Structural

\begin{tabular}{|l|l|l|l|l|l|}
\hline $\begin{array}{c}\text { Contextual Relationships between Elements (Results of } \\
\text { Treatment ISM VAXO / Main Obstacle) }\end{array}$ \\
\hline No. & E1 & E2 & E3 & E4 & E5 \\
\hline E1 & 1 & 1 & 1 & 0 & 0 \\
\hline E2 & 0 & 1 & 1 & 0 & 0 \\
\hline E3 & 0 & 0 & 1 & 0 & 0 \\
\hline E4 & 0 & 0 & 0 & 1 & 1 \\
\hline E5 & 0 & 0 & 1 & 0 & 1 \\
\hline
\end{tabular}

Sources: Personal Data (2019)

No. sub-Element

1 There Lecturer Its Not Minding Ranks

2 Less Applications WHOM Student Scientific Lecturer

3 Less intensity Teaching To Students

$4 \quad$ Maximal Lecturer in Conducting Research

And Service

$5 \quad$ Lecturer bit Passed Certification

\section{Reachability Matrix}

Reachability matrix obtained from structural self-interaction matrix (SSIM) by using a two-stage process. In the first stage, the alphabet is used to indicate the relationship between variables in the SSIM is replaced with "0" or "1". Values in reachability matrix depending on the type of relationship in the SSIM (Faisal, 2015) and are summarized in the following relationship:

1) If the relationship between the variables in one line with the other variables in the column is "V", then in the early reachability matrix, the entry line to "1" while the column entries between these two variables to "0";

2) If the relationship between the variables in one line with the other variables in the column is " $\mathrm{A}$ ", then in the early reachability matrix, the entry line to " 0 " while the column entries between these two variables to "1";

3) If the relationship between the variables in one line with the other variables in the column is " $\mathrm{X}$ ", then in the early reachability matrix, the entry line to "1" while the column entries between these two variables to "1";

4) If the relationship between the variables in one line with the other variables in the column is "O", then in the early reachability matrix, the entry line to " 0 " while the column entries between these two variables to "0".

Based on the above, the matrix reachability beginning to enabler aspects of the development of lecturers PAI improved. Furthermore, by incorporating the concept of transitivity, the matrix obtained reachability end. Transitivity the main obstacle is the basic assumption made in the ISM. This concept states that if the variable $\mathrm{X}$ is related to $\mathrm{Y}$ and $\mathrm{Y}$ linked to $\mathrm{Z}$, then $X$ must be linked to $Z[14]$, Reachability matrix also provides driving power (the power of influence) and the dependence of power of any enabler. Thus, in the last reachability matrix table, a driving power for the A1 (internal conditions) is the sum total of the values of entries in row, namely 5. Meanwhile, the dependence of power to the A1 (the number of entries in the column) is 4. Similarly, the values of driving power and power dependence are calculated for all the remaining enablers.

Table-3: Final Reachability Matrix (RM)

\begin{tabular}{|l|l|l|l|l|l|}
\hline \multicolumn{5}{|c|}{ Results of Treatment ISM VAXO Main Obstacle } \\
\hline No. & E1 & E2 & E3 & E4 & E5 \\
\hline E1 & 1 & 1 & 1 & 0 & 0 \\
\hline E2 & 0 & 1 & 1 & 0 & 0 \\
\hline E3 & 0 & 0 & 1 & 0 & 0 \\
\hline E4 & 0 & 0 & 0 & 1 & 1 \\
\hline E5 & 0 & 0 & 1 & 0 & 1 \\
\hline
\end{tabular}

Sources: Personal Data (2019)

Reachability end of the matrix, the next stage is to build reachability set and antecedent set. Range specified for the particular enabler itself consists of an enabler and other enablers that can help achieve them. Similarly, the antecedents set consisting of itself and enabler enabler that can influence it. The intersection of 
this set is derived for all enablers. Enabler which set intersection and reachability are equal, form the top level of the hierarchy in the model ISM. The Enabler will not help achieve another enabler above their level. The level identified help in building quadrant and the final model ISM.

\section{Quadrant Analysis MICMAC}

In his research, Godet [15] have popularized the cross-impact matrix multiplication or matrix multiplications Cross Impact of Applied to Classification (MICMAC) to classify the system variables analyzed. The basis of this classification is the driving power and dependence of power calculated in the final reachability matrix. In addition, MICMAC analysis can be used to examine the relationship between the direct and latent enabler obtained from ISM technique. So, based on Driving Power and Power Dependence, enabler in this study was classified into four groups, as shown and described below:

a. Autonomous Variable: This variable has no effect high power or high dependency. They are separated from the system, where they have some links that may be very strong. Quadrant I represent variable autonomous (autonomous). In this study, an enabler of 2 and 5 are fewer applications lecturers to students and faculty qualify for certification little falls into this category.

b. Dependent variable: Quadrant II is a dependent variable that has low influence strength and a high dependency. From the MICMAC analysis, enabler 3 is the dependent variable. The dependent variable is less intensity teaching for students.

c. Linkage variables: These variables have high impact power dependency is also high at the same time. Its characteristic is that any action on them will have an effect on the variables above their level and feedback effects on themselves. Quadrant III is a variable linkage. In this study there are enablers produced by experts.

d. Independent Variable: This variable has a high influence and low dependence. They represent Quadrant IV. In this study, the enabler 1 and 4 are still lazy professors who take care of rank and lecturers who have not been up to conduct research and dedication, are included in this category.

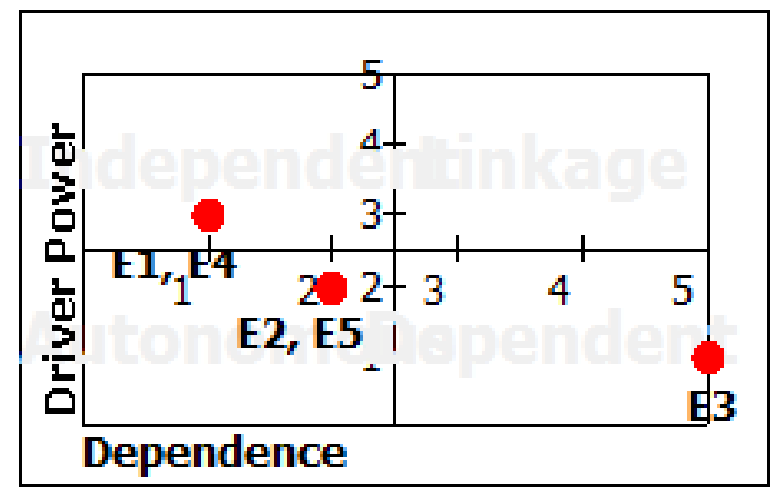

Fig-3: Main Constraints Analysis Aspects MICMAC Sources: Personal Document

Element aspects of the main obstacles in the strategy to improve the quality of lecturers PAI in Kopertais Region 1 Jakarta are translated into five (5) sub-elements as follows: (E1) artifacts lecturers who do not take care of rank, (E2) less the application of science faculty to students (E3), less the increase teaching faculty to students, (E4) maximal faculty in conducting research and dedication, and (E5) at least lecturer escaped certification. The results of the ISM's processing element main aspects of the development of quality human resource constraints Prodi PAI lecturers in Kopertais Region 1 Jakarta can be seen below, with details as follows:

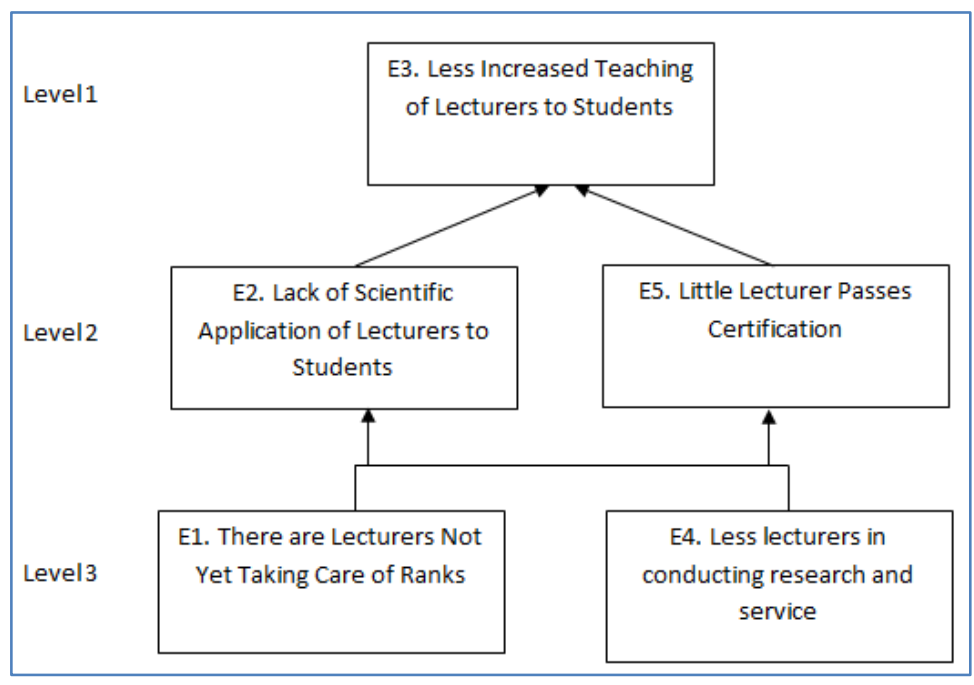

Fig-4: Structure Model Elements Aspects Main Obstacle

Sources: Personal Document

The picture above shows the sequence of strategies for developing Islamic education lecturers in
Kopertais Region 1 Jakarta. Whereas for the most recent level level 3 which is a sub element of the key 
elements of the main obstacle aspect, namely the condition of the lecturer being lazy to do promotion and the maximum faculty in conducting positive research and service activities has the greatest impact in Applying the strategy to improve the quality of lecturers of Islamic religious education departments in In the future Kopertais Wilayah 1 Jakarta, it is hoped that if strong support for faculty upgrading from the Islamic education department can produce more optimal level variables above it. Through level 2, which is the application of the faculty of science to students and the difficulty of lecturers meeting lecturer certification requirements, it is expected that Islamic religious study programs will be able to improve the quality of teaching to students and BKD archiving inventory for certification needs, with the main obstacle in improving the quality of lecturers in Islamic religious education can be solved. Furthermore, level 1 less than the intensity of teaching lecturers to students will be handled properly when levels 2 and 3 have been carried out by the parties concerned, especially lecturers of Islamic religious education continue to reform themselves and stakeholders to motivate lecturers of Islamic religious education in improving quality, by the main obstacle in improving the quality of lecturers of Islamic Religious Education Study Programs can be resolved. Furthermore, level 1 less than the intensity of teaching lecturers to students will be handled properly when levels 2 and 3 have been carried out by the parties concerned, especially lecturers of Islamic religious education continue to reform themselves and stakeholders to motivate lecturers of Islamic religious education in improving quality, by the main obstacle in improving the quality of lecturers of Islamic Religious Education Study Programs can be resolved. Furthermore, level 1 less than the intensity of teaching lecturers to students will be handled properly when levels 2 and 3 have been carried out by the parties concerned, especially lecturers of Islamic religious education continue to reform themselves and stakeholders to motivate lecturers of Islamic religious education in improving quality.

\section{Elements of Program Objectives}

The elements of the program objectives that might be encountered in terms of improving the quality of Islamic religious education lecturers in Kopertais Region 1 Jakarta are broken down into five (5) sub elements as follows: (A1) Achievement of improving lecturer (professional) quality (A2) Kopertais lecturers with PTKIS achievement, (A3)) Lecturers who get achievement get proper incentives/allowances, (A4) Lecturers who get allowances will improve quality, and (A5) Certified lecturers will get welfare.

ISM processing results show the sequence of program objectives in improving the quality of Islamic religious education lecturers in Kopertais Region 1 DKI Jakarta. In general there are 2 levels of sub-elements. As the picture below:

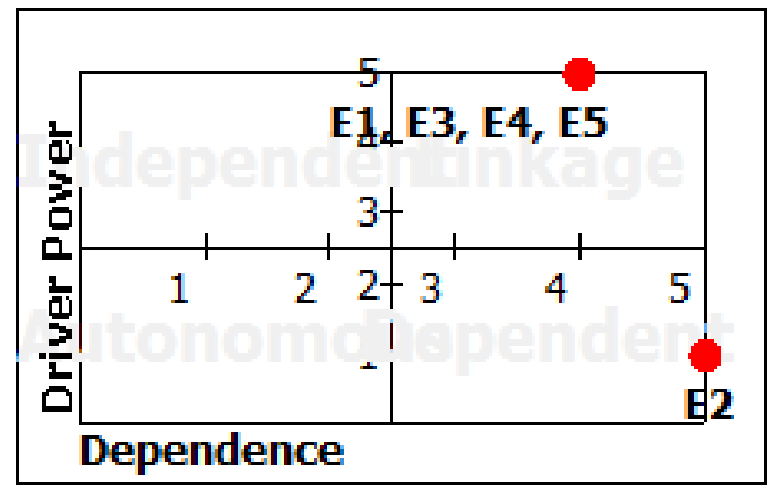

Fig-5: Analysis of Program Objectives Aspects MICMAC Sources: Personal Document

From the picture above is known that E1, E2, E4 and E5 are at Linkage Variable variables: These variables which have a high impact at a time dependency is also high. Its characteristic is that any action on them will have an effect on the variables above their level and feedback effects on themselves. Quadrant III is a variable linkage. Mean while E2 is the variable that has the power influence of high and low dependence. They represent Quadrant IV.

As for the priority elements of the program's objectives in order to improve the quality of lecturers Prodi Kopertais PAI in Region 1 Jakarta described as shown below:

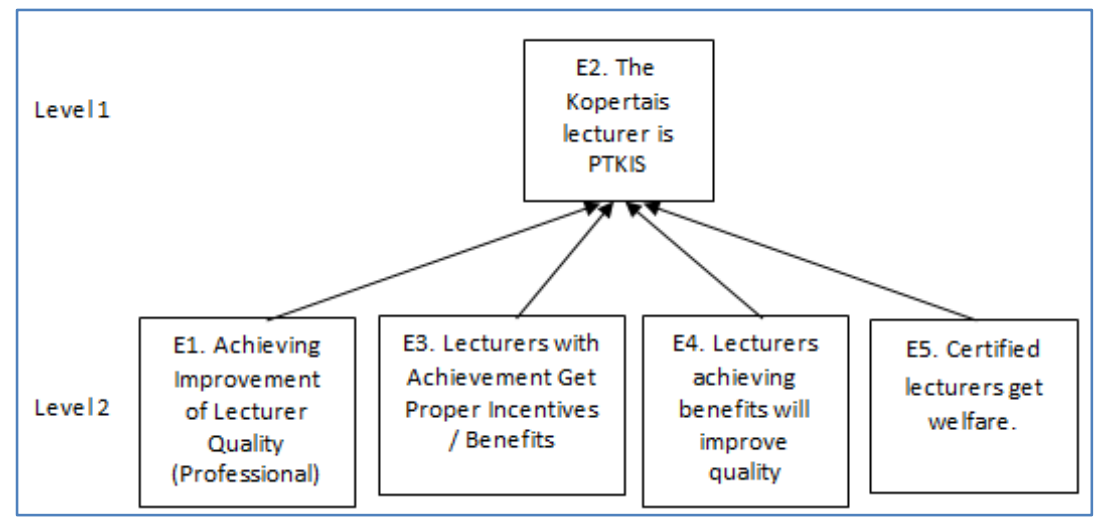

Fig-6: Model Elements Structural Aspects of Program Objectives 
Sources: Personal Document

These results indicate that everything that must be considered and prioritized by the DKI Jakarta Kopertais Region 1 environment that fosters Islamic religious education lecturers in order to improve the quality of lecturers on the element of "Program Objectives" includes the achievement of improving the quality of lecturers (professional) (E1) Achieved lecturers get appropriate incentives (E3), lecturers receive allowances will improve quality (E4), and certified lecturers get welfare (E5) are in the lowest level level, ie level 2. From the information, each PTKIS who is guided by Kopertais Region 1 DKI Jakarta must continue to innovate to improve the quality of Islamic religious education lecturers, from these four programs it is expected to be able to motivate Islamic religious education lecturers to improve their quality.

Meanwhile, the level above that is level 1 in the element of program objectives in improving the quality of Islamic Religious Education lecturers in Kopertais Region 1 DKI Jakarta is Kopertais Lecturer in Homepage at PTKIS, then with the aim of the program lecturers of Islamic religious education will be able to improve their quality of performance performance. Professional in every activity.

\section{Elements Related Institutions}

The institutional elements involved in the strategy to improve the quality of Islamic religious education lecturers in DKI Jakarta Region 1 Kopertais are described in 4 (four) sub elements as follows: (A1) DKI Jakarta Region 1 Kopertais, (A2) PTKIS / University Leaders, (A3) Faculties PTKIS Islamic Religion, (A4) Islamic religious education study program at every PTKIS.
The ISM processing results show the order in the related institutional elements as can be seen in the figure below:

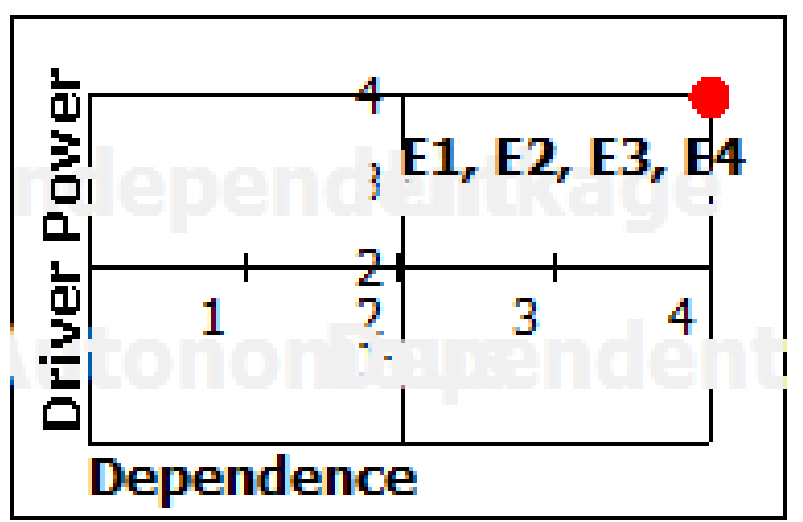

Fig-7: Analysis of Institutions Related Aspects MICMAC

Sources: Personal Document

From the picture above, each sub element is in quadrant III or Linkage variable, this variable has a high influence power as well as a high dependency as well. Its characteristic is that every action on them will have an effect on variables above their level and a feedback effect on themselves.

Then, in implementing the strategy to improve the quality of Islamic religious education study program lecturers in the DKI Jakarta Region 1 Kopertasi, each of each institution influences and interrelates one another in improving the quality of Islamic religious education lecturers starting from the DKI Jakarta Region 1 Kopertais, PTKIS / University Leaders, Faculty of Islamic Religion and Islamic religious education study programs in each Faculty. Like the picture below:

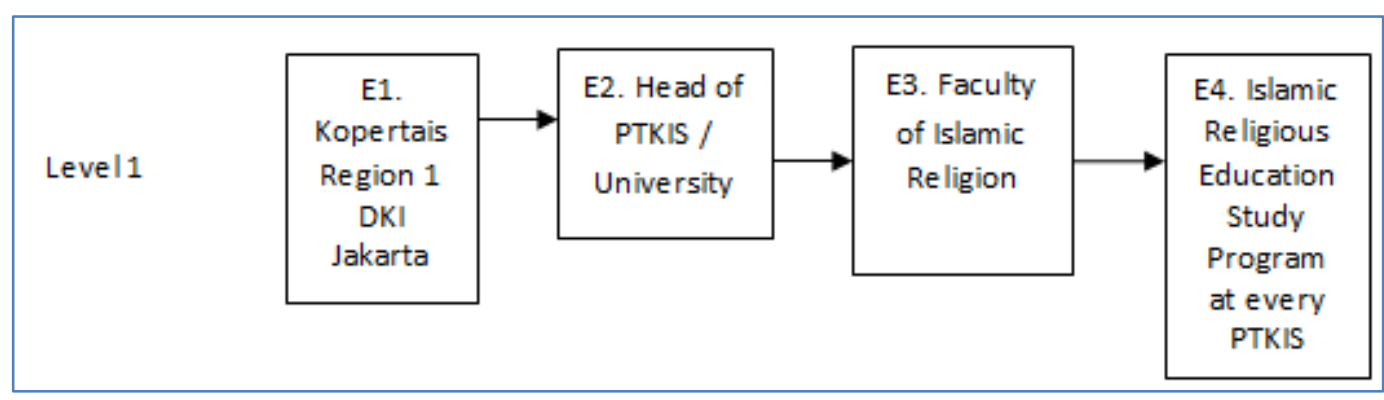

Fig-8: Structure Model Elements Related Aspects of Institutions

Sources: Personal Document

The linkages are expected to be able to synergize with each other. Thus improving the quality of Islamic religious education lecturers will not be achieved when the interrelated institutions do not have the same goal in creating good quality education. Among the indicators to create good quality education is to continue to make regulations and policies to improve the quality of lecturers, this aims to make lecturers more motivated to innovate in order to improve their quality.

\section{CONCLUSION}

As the description above about the results and discussion of research strategies to improve the quality of lecturers of Islamic religious education study programs in Kopertais Region 1 DKI Jakarta with the ISM approach, the conclusions can be drawn as follows: 
First, in the main obstacle element found the key element is the condition of lecturers who have not been maximally promoted and the lecturers less than optimal in conducting research activities and positive service has the most influence in implementing strategies to improve the quality of Islamic religious lecturers in Kopertais Region 1 DKI Jakarta to forward, then if there is strong support for improvement of Islamic religious education lecturers to be more optimal.

Second, in the element of program objectives Achievement in improving the quality of lecturers (professional), Lecturers with high achievement incentives/allowances, Lecturers achieving benefits will improve quality, and Certified Lecturers get welfare. So every PTKIS that is guided by the DKI Jakarta Region 1 Kopertais is required to innovate to improve the quality of Islamic religious education lecturers, from the four programs it is expected to be able to motivate Islamic religious education lecturers to improve their quality.

Third, found in the related institutional elements, each from each institution influencing and interrelating each other in improving the quality of lecturers of Islamic religious education starting from Kopertais Region 1 DKI Jakarta, Leaders of PTKIS /University, Faculty of Islamic Religion and Islamic religious education study programs in each Faculty.

\section{REFERENCE}

1. Nasir, M. (2013). Profesionalisme Guru Agama Islam: Sebuah Upaya Peningkatan Mutu Melalui LPTK. Dinamika Ilmu, 13(2).

2. Basyar, S. (2016). Manajemen Mutu Pendidikan Perguruan Tinggi Keagamaan Islam Dalam Meningkatkan Kualitas Mahasiswa. Jurnal Dewantara, 1(01), 1-15.

3. Fauzi, A. (2018). Human Resource Management dalam Meningkatkan Mutu Dosen PTKIS. AtTa'lim: Jurnal Pendidikan, 4(1), 21-34.

4. Barney, J. B. (1986). Organizational culture: can it be a source of sustained competitive advantage?. Academy of management review, 11(3), 656-665.

5. Farchan, F. (2018). Strategi msdm sebuah cara menciptakan kinerja organisasi dalam mencapai keunggulan bersaing. Risâlah, Jurnal Pendidikan dan Studi Islam, 4(1, March), 42-52.

6. Mahaya, G. (2017). Strategi meningkatkan motivasi kerja karyawan BMT Marhamah Purworejo (Doctoral dissertation, UIN Walisongo).

7. Kusnan, K. (2018). Kebijakan Mutu Peningkatan Dosen. Jurnal Ilmiah Iqra', 11(2).

8. Piscayanti, K. S. (2015). Pengaruh Sertifikasi Dosen Terhadap Kinerja Pengajaran Dosen Undiksha. Jurnal Ilmu Sosial dan Humaniora, 4(1).

9. Siregar, T., \& WALUKOW, A. (2014). Pengaruh Pemberian Tunjangan Sertifikasi, Dan Motivasi Kerja Terhadap Kinerja Dosen Ipa Jurusan P. Mipa Uncen. Jurnal Ilmu Pendidikan Indonesia, 2(2), 19.

10. Syahrizal, S. (2016). Pengembangan kompetensi dosen pendidikan agama islam (pai) dalam menghadapi era globalisasi. JURNAL TARBIYAH, 22(1).

11. Sianipar, M. (2012). Penerapan Intrepretative Structural Modeling (ISM) dalam penentuan elemen pelaku dalam pengembangan kelembagaan sistem bagi hasil petani kopi dan agroindustri kopi. Agrointek: Jurnal Teknologi Industri Pertanian, 6(1), 8-15.

12. Rusydiana, A. (2018). Aplikasi Interpretive structural modeling untuk strategi pengembangan wakaf tunai di Indonesia. Jurnal Ekonomi dan Bisnis Islam (JEBIS), 4(1), 1-17.

13. Rusydiana, A. S. (2018). Analysis Of Cash Waqf Development In Indonesia Using Interpretive Structural Modeling (ISM). Journal of Islamic Economics Lariba, 4(1), 1-11.

14. Rusydiana, A. S. (2018). Bagaimana Mengembangkan Industri Fintech Syariah di Indonesia? Pendekatan Interpretive Structural Model (ISM). Al-Muzara'ah, 6(2), 117-128.

15. Godet, M. (1986). Introduction to la prospective: seven key ideas and one scenario method. futures, 18(2), 134-157. 